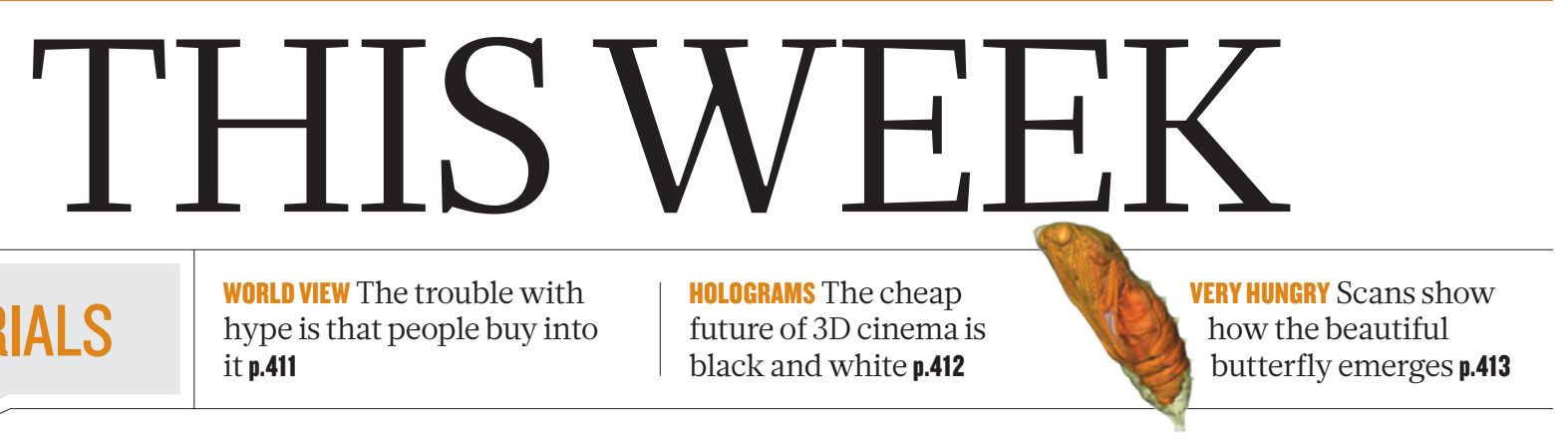

\title{
Double vision
}

\section{Scientists must ensure that they take the lead in the ethical debate surrounding the therapeutic use of stem cells derived from human clones.}

$\mathrm{L}$ ast week's announcement in Cell that a team in Oregon has successfully derived stem cells from a cloned human embryo raises many questions. Researchers must do their best to answer them. If they do not, then they risk a repeat performance of the misinformation, confusion and distraction that followed the birth in 1996 of the first mammalian clone, Dolly the sheep. Nonsense such as rumours that Saddam Hussein was going to copy himself, claims by the Raëlian sect that it had produced a cloned girl named Eve and declarations by physicist and entrepreneur Richard Seed that he would produce hundreds of thousands of human clones generated an environment of fear that distracted from the real debate and set back research.

The reaction to the Oregon team's success has been predictably mixed. Some have lauded the achievement, others have been less enthusiastic. "Barbaric," wrote one critic. Another called it a "terrible injustice".

It is true that the research faces ethical controversy on three fronts: egg donation, embryo destruction and cloning. The work needs eggs to be donated by women, who must undergo a procedure that carries risks of complications. If the research ultimately produces promising medical therapies, will we see a group of women marshalled to feed this therapeutic intervention? The procedure also requires the destruction of early-stage embryos, which many oppose, usually on religious grounds. And many criticize the fact that the procedure starts down the same path as reproductive cloning, suggesting that to advance the technology will inevitably result in reproductive cloning of humans.

These are serious points and they need to be considered. But the reality is that, if anything, the latest research suggests that the chance of creating a cloned human is more remote than it seemed two weeks ago. No group has put more effort into trying to clone monkeys reproductively than the Oregon scientists. Yet after nearly two decades of trying, they have yet to succeed. They conclude that their method, optimized for producing embryonic stem-cell lines from cloned embryos, probably cannot be used for reproductive cloning.

Still, given the controversy that surrounds this work, some argue that researchers should stick to alternatives such as induced pluripotent stem (iPS) cells. Like cloned stem cells, these offer patient-specific cells with embryo-like developmental potential, but crucially they do not require egg recruitment, embryo destruction or cloning. Leading iPS-cell researchers are now keen to compare these cells with the cloned stem cells to help them to evaluate and improve iPS cells. Until that work is done, it will be hard to say whether iPS cells are, or can be, reprogrammed to function as effectively cloned cells.

But this research will move slowly, at least in the United States. Because production of the cloned cells requires the destruction of embryos specifically created for research, US laboratories funded by the taxpayer through the National Institutes of Health cannot use the technique, nor can they work with the stem cells created by it. Progress

will depend on the few laboratories with sufficient private funds.

Whatever the outcome of those investigations, there are some clinical applications for which cloned stem cells could be the best option. Cloned cells contain the nuclear DNA of whoever is being cloned but they also hold the mitochondrial DNA from the egg

"Armies of

cloned despots

are the last

thing we need to

worry about." tioning cells to the right place and to make sure that they continue to work? Can enough of the cells with faulty mitochondrial DNA be replaced by the cloned ones?

Experiments that follow up on the Oregon team's advance will be especially valuable. If they don't prove that the technique is worth the controversy, it will no doubt fall into disuse. If it does prove to have therapeutic promise, questions of egg donation will need to be re-evaluated. Either way, armies of clones or cloned despots are the last thing we need to worry about.

\section{Uncertain times}

\section{Budgetary delays exacerbate dire outlook for US research.}

$\mathrm{N}$ early three months into the across-the-board budgetary cuts known as sequestration, the US Congress seems as petulant and ineffectual as ever. There is no end in sight to the national economic stalemate driven by Senate Democrats, House Republicans and President Barack Obama. Congress has made only a few halfhearted and piecemeal attempts to fix some of the sequestration cuts, such as loosening restrictions on Federal Aviation Administration funds so that air-traffic controllers can get back to work. No such deals have been forthcoming for science agencies or research.

Before sequestration took effect on 1 March, science advocates had warned that the cuts would have dire consequences (see Nature 494, 401-402; 2013). Major agencies such as the National Science Foundation would issue at least 1,000 fewer grants. Workers for federal agencies and at national laboratories would be forced to take unpaid leave, or even be laid off altogether. An entire generation of young scientists would be driven out of the field and into other careers.

Those grim predictions - or at least some of them - are now 